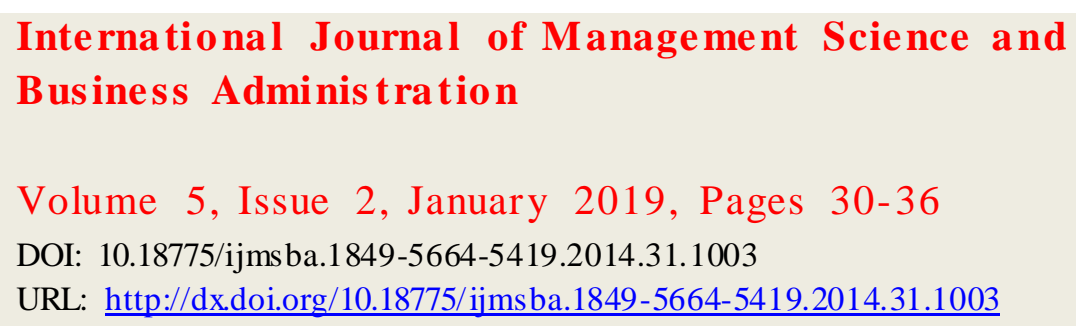

\title{
Impact of Welfare Measures on the Quality of Employees Performance with Special Reference to Construction Industry
}

\author{
${ }^{1}$ A. Varadaraj, ${ }^{2}$ D. Charumathi \\ ${ }^{1}$ Alliance School of Business, Alliance University, Bengaluru, Karnataka, India \\ ${ }^{2}$ Measi Institute of Management, Chennai, Tamil Nadu, India
}

\begin{abstract}
The concept of employee welfare is vibrant. Its broad viewpoint and contents are inclined to change, depending on social and economic changes that occur in society. Employee welfare includes various services, benefits and facilities offered to employees by the employers. An organization has to provide welfare facilities to their employees to keep their motivation levels high. The study throws light on impact of welfare measures on the employees' performances with respect to the construction industry. The primary data for the study was collected through a questionnaire. The sample size of the study was 80 and the sample design adopted was systematic random sampling technique.
\end{abstract}

Keywor ds: Welfare, Performances, Measures, Impact

\section{Introduction}

An employee who feels appreciated will further be comfortable, satisfied and more prolific. It has leads not only towards higher productivity but also improves the quality of performance which helps to capture the market share which is profitable for the company. A satisfied employee will not look into for other job opportunities and it enables an employer to keep the best talents and record lower employee turnover. Welfare includes anything that is done for the comfort and improvement of employees and is facilitated with over and above the wages. The provision of welfare measures helps in keeping the morale and motivation of the employees high to retain the employees for a longer duration. The welfare measures need not be in monetary terms only, it can also be in any forms. Employee welfare includes monitoring of working conditions, creation of industrial harmony through infrastructure for health, industrial relations and insurance against disease, accident and unemployment for the workers and their families. Employee welfare is a comprehensive term including various services, facilities and amenities provided to employees for their betterment. Welfare measures are something that is available to employees in addition to regular wages and other economic benefits under legal provisions and collective bargaining. The perseverance of employee welfare is to improve the working class which in turn makes a worker a good employee and a happy citizen. Employee welfare is an indispensable part of social welfare. It involves a balance between an employee's work life and family life to the community or social life.

\section{Objectives of the study:}

- To study the impact of employee welfare measures.

- To study the level of employee satisfaction towards the welfare facilities offered at ETA.

To suggest the measures to improve the welfare measures to enhance the performance of the employees.

\section{Literature Review}

P. Anju (2016) in the study identified that the rate of absenteeis mhad been reduced to a great extent by providing housing, health and family care, canteen, educational and training facility and provision of welfare activities. He also stated that this principle for successfulimplementation of labor welfare activities is nothing but an extension of democratic values in an industrialized society. 
Mr. Ramana T. Ventata (2015) finds that the welfare facilities are provided to the employees to keep the motivation levels high. He states that the intramural and extramural welfare measures offered to the employees have improved their rate of satisfaction towards job.

Dr. P. Venugopal and T. Bhaskar (2011) found that employees are satisfied with welfare measures such as recreational, medical, educational, housing, transportation, sanitation, safety. The employees are also satisfied towards statutory welfare measures such as Workmen Compensation, ESI, Sickness, P.F and Maternity benefits. These measures have an impact on the quality of work life and also on the smooth relationship between employer and employee which leads towards the attainment of organization goals.

Dr. Usha Tiwari (2014) conducted a study on the employees' welfare facilities and its impact on employees. It was a lso further reiterated that the management should provide facilities to all employees in such way that employees become satisfied on the welfare facilities which in turn leads to increase in productivity in terms of quality and quantity.

Dr.P.Bhujanga Rao(2017) state that welfare measure is a process of recognizing the unique place of the worker in the society and doing good for them, retaining and motivating employees and building up the local reputation of the company.

\section{Methodology}

The Researcher used Descriptive Research Design in this research. Primary Data was collected through questionnaire and, secondary data are from journals, books, and websites. The data were edited, coded, classified and tabulated for analysis. The sampling technique used by the researcher is Systematic Random Sampling. Sample size taken for the study is 80 .

\section{Data Analysis and Interpretations}

\subsection{Pilot Study}

A pilot study, pilot project or pilot experiment is a small scale preliminary study conducted to ev aluate feasibility, time, cost, adverse events, and effect size (statistical variability) in an attempt to predict an appropriate sample size and impro ve upon the study design before performance of a full scale. Pilot study was done with 10 respondents.

\subsection{Reliability Test}

Table 1: showing the reliability test

Reliability Statistics

\begin{tabular}{|l|l|}
\hline Cronbach's Alpha & N of Items \\
\hline 0.828 & 44 \\
\hline
\end{tabular}

Inference: Cronbach alpha value of the reliability test is 0.828 which is more than 0.75 . Hence the questionnaire is highly reliable.

Table 2: showing chi-square to show the association between welfare measures and physical and mental health of employees.

\section{Null hypothesis}

There is no significant difference between department and impact of welfare measures towards the improvement of physical and mental health.

\section{Alternate hypothesis}

There is significant difference between department and impact of welfare measures towards improvement of physical and mental health.

Table 2: Chi-square 


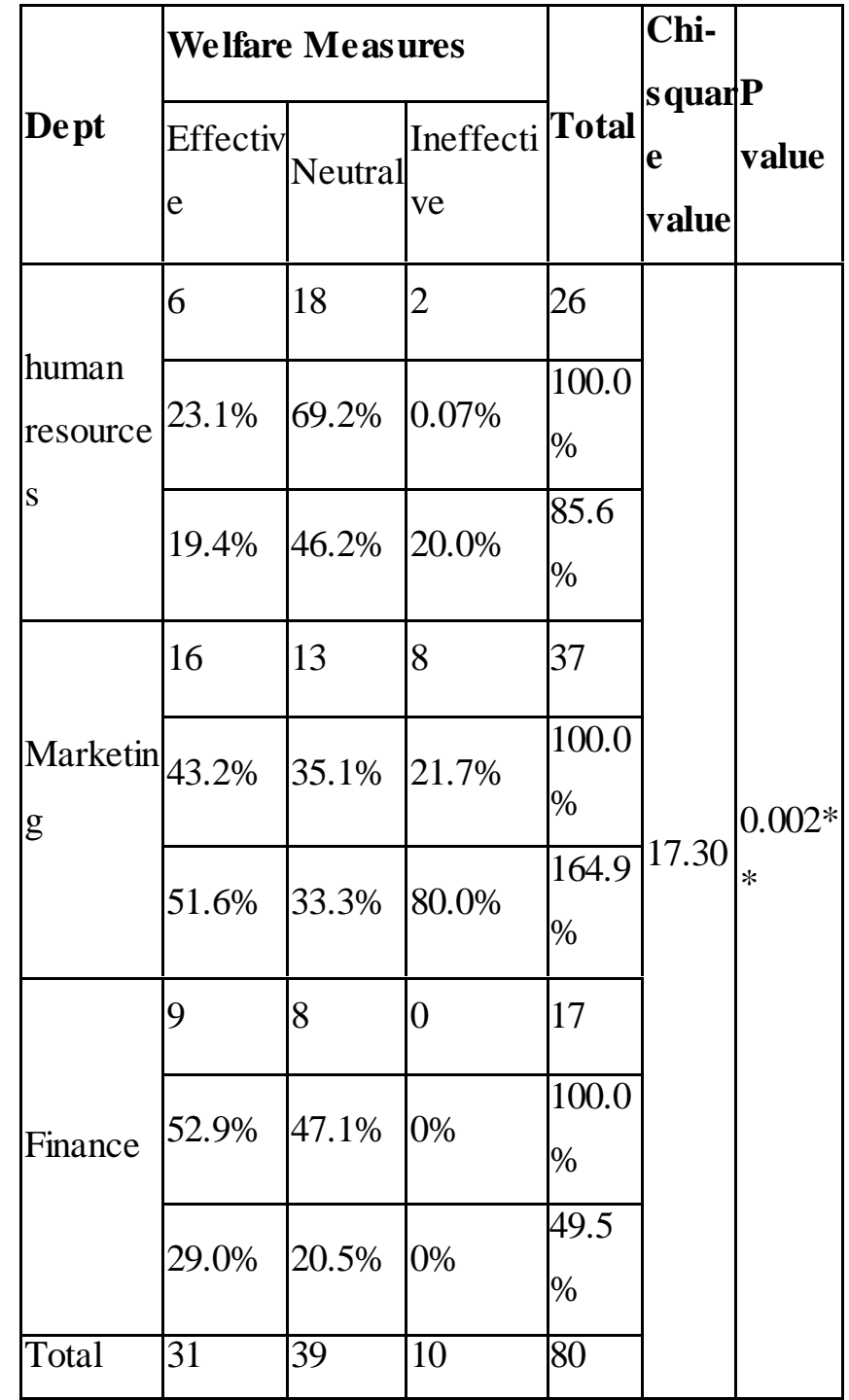

Since p-value is $<0.05$

Reject the null hypothesis

Accept the alternate hypothes is

Inference: Since the p-value is less than 0.05 , the null hypothesis is not accepted and, the alternate hypothesis is accepted. There is a significant difference between department and impact of welfare measures towards the improvement of physical and mental health. Each department has a different form of workload and work stress and creates an impact on employees' physical and mental health. Welfare measures like seating arrangements, medical facilities, and recreation facilities should be provided effectively.

Table 3: showing ANOVA test the opinions of employees towards welfare measures with their experience Null Hypothesis: There is no significant difference between the opinions of employees towards welfare measures with the experience of employees.

Alternate Hypothesis: There is a significant difference between the opinions of employees towards welfare measures with the experience of employees.

Table 3: ANOVA test 


\begin{tabular}{|c|c|c|c|c|c|c|}
\hline $\begin{array}{l}\text { Attribute } \\
\text { S }\end{array}$ & & $\begin{array}{l}\text { Sum of } \\
\text { Square }\end{array}$ & Df & $\begin{array}{l}\text { Mean } \\
\text { Square }\end{array}$ & $\mathbf{F}$ & Sig. \\
\hline \multirow{3}{*}{$\begin{array}{l}\text { Medical } \\
\text { facilities }\end{array}$} & $\begin{array}{l}\text { Between } \\
\text { Groups }\end{array}$ & 3.535 & 2 & 1.767 & \multirow[t]{3}{*}{3.146} & \multirow[t]{3}{*}{.049} \\
\hline & $\begin{array}{l}\text { Within } \\
\text { Groups }\end{array}$ & 43.265 & 77 & .562 & & \\
\hline & Total & 46.800 & 79 & & & \\
\hline \multirow{3}{*}{$\begin{array}{l}\text { Insurance } \\
\text { facilities }\end{array}$} & $\begin{array}{l}\text { Between } \\
\text { Groups }\end{array}$ & 9.105 & 2 & 4.553 & \multirow[t]{3}{*}{9.119} & \multirow[t]{3}{*}{.000} \\
\hline & $\begin{array}{l}\text { Within } \\
\text { Groups }\end{array}$ & 38.445 & 77 & .499 & & \\
\hline & Total & 47.550 & 79 & & & \\
\hline $\begin{array}{l}\text { Education } \\
\text { Facilities }\end{array}$ & $\begin{array}{l}\text { Between } \\
\text { Groups } \\
\text { Within } \\
\text { Groups } \\
\text { Total }\end{array}$ & $\begin{array}{l}56.553 \\
64.800\end{array}$ & $\begin{array}{l}77 \\
79\end{array}$ & 4.123 & 5.614 & .005 \\
\hline \multirow[b]{2}{*}{$\begin{array}{l}\text { Housing } \\
\text { Facilities }\end{array}$} & $\begin{array}{l}\text { Between } \\
\text { Groups }\end{array}$ & 17.601 & 2 & 8.800 & \multirow[t]{2}{*}{$\begin{array}{l}19.69 \\
9\end{array}$} & \multirow[t]{2}{*}{.000} \\
\hline & $\begin{array}{l}\text { Within } \\
\text { Groups } \\
\text { Total }\end{array}$ & $\begin{array}{l}34.399 \\
52.000\end{array}$ & $\begin{array}{l}77 \\
79\end{array}$ & .447 & & \\
\hline \multirow{3}{*}{$\begin{array}{l}\text { Good } \\
\text { Working } \\
\text { Environm } \\
\text { ent }\end{array}$} & $\begin{array}{l}\text { Between } \\
\text { Groups }\end{array}$ & 12.295 & 2 & 6.148 & \multirow[t]{3}{*}{$\begin{array}{l}14.30 \\
5\end{array}$} & \multirow[t]{3}{*}{.000} \\
\hline & $\begin{array}{l}\text { Within } \\
\text { Groups }\end{array}$ & 33.092 & 77 & .430 & & \\
\hline & Total & 45.388 & 79 & & & \\
\hline \multirow{3}{*}{$\begin{array}{l}\text { Transport } \\
\text { Facilities }\end{array}$} & $\begin{array}{l}\text { Between } \\
\text { Groups }\end{array}$ & 4.839 & 2 & 2.419 & \multirow[t]{3}{*}{4.321} & \multirow[t]{3}{*}{.017} \\
\hline & $\begin{array}{l}\text { Within } \\
\text { Groups }\end{array}$ & 43.111 & 77 & .560 & & \\
\hline & Total & 47.950 & 79 & & & \\
\hline
\end{tabular}

Inference: Since the p-value is less than 0.05 , the null hypothesis is not accepted with respect to medical facilities, insurance facilities, education facilities, housing facilities. Good working environment and transport facility that is offered as welfare measures. Hence there is a significant difference between the opinions of employ ees towards welfare measures concerning their experience. New employees may have one kind of expectation and employees who have more experience may expect a different set of welfare measures. Therefore the experiences of the employees should be considered as a factor while improvising the welfare measures. 


\section{A.Varadaraj, D.Charumathi}

Impact of Welfare Measures on the Quality of Employees Performance with Special Reference to Construction Industry

Table 4 showing the Anova Test showing the difference between gender and the satisfaction towards welfare measures provided at the construction industry.

\section{Null Hypothesis:}

There is no significant difference between gender and satisfaction towards welfare measures.

\section{Alternate Hypothesis:}

There is a significant difference between gender and satisfaction towards welfare measures.

Table 4: Anova Test

\begin{tabular}{|c|c|c|c|c|c|c|}
\hline Attributes & & $\begin{array}{l}\text { Sum of } \\
\text { Squares }\end{array}$ & Df & $\begin{array}{l}\text { Mean } \\
\text { Square }\end{array}$ & $\mathbf{F}$ & Sig. \\
\hline \multirow{3}{*}{$\begin{array}{l}\text { Medical } \\
\text { facilities }\end{array}$} & $\begin{array}{l}\text { Between } \\
\text { Groups }\end{array}$ & 38.896 & 2 & 19.448 & \multirow[t]{3}{*}{14.010} & \multirow[t]{3}{*}{0.000} \\
\hline & Within Groups & 188.787 & 136 & 1.388 & & \\
\hline & Total & 227.683 & 138 & & & \\
\hline \multirow{3}{*}{$\begin{array}{l}\text { Insurance } \\
\text { facilities }\end{array}$} & $\begin{array}{l}\text { Between } \\
\text { Groups }\end{array}$ & 55.891 & 2 & 27.946 & \multirow[t]{3}{*}{25.126} & \multirow[t]{3}{*}{0.000} \\
\hline & Within Groups & 151.260 & 136 & 1.112 & & \\
\hline & Total & 207.151 & 138 & & & \\
\hline $\begin{array}{l}\text { Education } \\
\text { Facilities }\end{array}$ & $\begin{array}{l}\text { Between } \\
\text { Groups } \\
\text { Within } \\
\text { Groups } \\
\text { Total }\end{array}$ & $\begin{array}{l}42.841 \\
185.216 \\
228.058\end{array}$ & $\begin{array}{l}136 \\
138\end{array}$ & 21.421 & 15.729 & 0.000 \\
\hline \multirow{2}{*}{$\begin{array}{l}\text { Housing } \\
\text { Facilities }\end{array}$} & $\begin{array}{l}\text { Between } \\
\text { Groups }\end{array}$ & 31.267 & 2 & 15.634 & \multirow[t]{2}{*}{10.394} & \multirow[t]{2}{*}{0.000} \\
\hline & $\begin{array}{l}\text { Within } \\
\text { Groups } \\
\text { Total }\end{array}$ & $\begin{array}{l}204.560 \\
235.827\end{array}$ & $\begin{array}{l}136 \\
138\end{array}$ & 1.504 & & \\
\hline \multirow{3}{*}{$\begin{array}{l}\text { Good Working } \\
\text { Environment }\end{array}$} & $\begin{array}{l}\text { Between } \\
\text { Groups }\end{array}$ & 53.657 & 2 & 26.828 & \multirow[t]{3}{*}{20.285} & \multirow[t]{3}{*}{0.000} \\
\hline & $\begin{array}{l}\text { Within } \\
\text { Groups }\end{array}$ & 179.868 & 136 & 1.323 & & \\
\hline & Total & 233.525 & 138 & & & \\
\hline \multirow{3}{*}{$\begin{array}{l}\text { Transport } \\
\text { Facilities }\end{array}$} & $\begin{array}{l}\text { Between } \\
\text { Groups }\end{array}$ & 38.896 & 2 & 19.448 & \multirow[t]{3}{*}{14.010} & \multirow[t]{3}{*}{0.000} \\
\hline & $\begin{array}{l}\text { Within } \\
\text { Groups }\end{array}$ & 188.787 & 136 & 1.388 & & \\
\hline & Total & 227.683 & 138 & & & \\
\hline
\end{tabular}


Since $\mathrm{p}$-value is $<0.05$

Reject the null hypothesis.

\section{Inference:}

Since the p-value is less than 0.05 , the null hypothes is is overruled with respect to gender and welfare measures offered to the employee's viz., medical facilities, insurance facilities, education facilities, housing facilities, good working environment, and transport facility that is offered as welfare measures offered and its impact on satisfaction of employees. Hence, there is a significant difference between the satisfaction of employees towards welfare measures with the gender of the employees. The satisfaction of employees towards welfare measures differs based on gen der. The preference of the employees towards welfare measure varies as per gender and management should take into consideration this factor while framing employee's welfare measures.

\section{Discussions and Implications}

- There is a significant difference between department and impact of welfare measures towards the improvement of physical and mental health. Each department has a different form of workload and work stress and creates an impact on employees' physical and mental health. Welfare measures like seating arrangements, medical facilities, and recreation facilities should be offered effectively to the employees.

- There is a significant difference between the opinions of employees towards welfare measures with their experience of the employees. The opinions of employees towards welfare measures differ based on their experiences. New employees may have one kind of expectations and employees who have more experience may expect a different set of welfare measures. Therefore the experiences of the employees should be considered as a factor while improvising the welfare measures.

\section{Conclusion}

Employee welfare is a comprehensive term including various services, facilities, and services provided to employees for their furtherance. Thus from this study, it is found that the welfare measures provided by the Construction industry directly impact the work competence of the employees. Proper welfare measures should be provided to persuade the employees and increase proficiency and effectiveness. The Company should take steps to create awareness among the employees about the welfare measures provided as it falls under the rights of the employee to know about the welfare measures provided for him/her by the company.

\section{References}

- Armstrong. (1988). Human Resource and Personnel Management (3rd Ed.). New Delhi: Tata McGraw Hill Publishing Company Limited.

- Aswathappa, K. (2003). Human Resource and Personnel Management (3rd Ed.). New Delhi: Tata McGraw Hill Publishing Company Limited.

- Bhagat S., D. (2015). "Employee Welfares Measures in medium scale industry which concentrate on statutory Welfare Measures in Nashik MIDC'. International Journal of Management Research \& Review, 5, 113-116.

- Kerk Aldy, P. (1995). Labour Welfare \& Job Satisfaction. New Delhi: Deep and Deep Publications.

- Khan, A. (1981). Labor Welfare \& Job Satisfaction. New Delhi: Deep and Deep Publications.

- Kholi, A., \& Sharma, S. (1997). Labour Welfare and Social Security (1st Ed.). New Delhi: Anmol Publications Private Limited.

- Kumar, A. (2003). Labour Welfare \& Social Security: Awareness, Utilization, and Satisfaction of Labour Laws. New Delhi: Deep and Deep Publications.

- P.Swapna. (2011). "Employee/Labour Welfare Measures in Singareni Collieries Company Limited". International Journal, 3, 369-380.

- Prabakar, S. (2013). "Employees satisfaction \& welfare measures a case study with special reference to Don Bosco College of Arts \& Science, Sogathur, Dharmapuri”. A peered review International Journal, 3.

- Ramasatyanarayana, M. (2012). "Labour Welfare measures in cement industries in India”. International Journal of Physical and Social Sciences, 2 , 257-264. 


\section{A.Varadaraj, D.Charumathi}

Impact of Welfare Measures on the Quality of Employees Performance with Special Reference to Construction Industry

- Sumit, P. \&. (2013). "Employee Welfare Measures in Auto sector". International Journal of Business and Management Invention, 2, , 66-74.

- Swlvan, B. \& (2011). "Labour Welfare Measures-Step Stone of Healthy Industrial Relations". Journal of Contemporary Research in Management, , 39-50.

- Yashik, P. M. (2014). "A study about the Labour welfare and Social Security Measures in India". International Journal of Management, 2, 23-28. 